\title{
Why the Apple Doesn't Fall Far: \\ Understanding Intergenerational Transmission of Human Capital
}

\author{
by \\ Sandra E. Black \\ Department of Economics \\ UCLA, IZA and NBER \\ Paul J. Devereux \\ Department of Economics \\ UCLA and IZA \\ Kjell G. Salvanes \\ Department of Economics \\ Norwegian School of Economics, Statistics Norway and IZA
}

July 2004

*Author contact information: Black: sblack@econ.ucla.edu; Devereux: devereux@econ.ucla.edu; Salvanes: kjell.salvanes@,nhh.no. The authors would like to thank Marina Bassi for helpful research assistance. We also thank Maia Guell, Oskar Nordstrøm Skans, and participants at ESSLE, SoLE, ITAM, the CEPR Uppsala Workshop, Columbia, Brown, Duke, Florida, Arizona, FIU, Federal Reserve Bank of Cleveland, CREST, and at UCL for helpful suggestions. The views expressed here are those of the authors and do not necessarily represent those of the Federal Reserve Bank of San Francisco or the Federal Reserve System. 


\begin{abstract}
Parents with higher education levels have children with higher education levels. However, is this because parental education actually changes the outcomes of children, suggesting an important spillover of education policies, or is it merely that more able individuals who have higher education also have more able children? This paper proposes to answer this question with a unique dataset from Norway. Using the reform of the education system that was implemented in different municipalities at different times in the 1960s as an instrument for parental education, we find little evidence of a causal relationship between parents' education and children's education, despite significant OLS relationships. We find 2SLS estimates that are consistently lower than the OLS estimates, with the only statistically significant effect being a positive relationship between mother's education and son's education. These findings suggest that the high correlations between parents' and children's education are due primarily to family characteristics and inherited ability and not education spillovers.
\end{abstract}

Key words: Intergenerational mobility, Education, Educational reform.

JEL Classification: I21, J13, J24. 


\section{Introduction}

Parents with higher education levels have children with higher education levels. But why? There are a number of possible explanations. One is a pure selection story; the type of parent who has more education, earns higher salaries, etc, has the type of child who will do so as well, regardless. Another story is one of causation; obtaining more education makes you a different type of parent, and thus leads to your children having higher educational outcomes.

Distinguishing between these scenarios is important from a policy perspective. One of the key roles of publicly provided education in our society is to increase equality of opportunity, and many policies have been implemented to further that goal in recent years. ${ }^{1}$ A possible benefit of this type of education policy is the spillover effect on to later generations; having more educated citizens may have longer run effects by improving the outcomes of their children. However, the research to date has been limited in its ability to distinguish between selection and causation.

This paper proposes to provide evidence on the causal link between parents' and children's education by using a unique dataset from Norway. During the 1960s, there was a drastic change in compulsory schooling laws in Norway. Pre-reform, children were required to attend school through the seventh grade; after the reform, this was extended to the ninth grade, adding two years of required schooling. Additionally, implementation of the reform occurred in different municipalities at different times, starting in 1960 and continuing through 1972, allowing for regional as well as time series variation. Evidence in the literature suggests that these reforms had a large and

\footnotetext{
${ }^{1}$ For example, the "No Child Left Behind" program supported by President George W. Bush.
} 
significant impact on educational attainment which, in turn, led to a significant increase in earnings. ${ }^{2}$ As a result, the reform provides variation in parental education that is exogenous to parental ability and enables us to determine the impact of increasing parental education on children's schooling. Although the instrument only allows us to determine the impact of increasing parental education from seven to nine years, this may be an important starting point for identifying the intergenerational transmission of education.

Using this reform as an instrument for parental education, we find little evidence of a causal relationship between father's education and children's education, despite significant and large OLS relationships. We find a significant causal relationship between mother's education and her son's education but no causal relationship between mother's and daughter's educations. This suggests that high correlations between parental and children's education are due primarily to selection and not causation. It is important to note that we use Norwegian data. While Norway is similar to the United States and Great Britain in terms of educational attainment and educational institutions, its labor market institutions are more similar to other European countries.

The paper unfolds as follows: Sections 2 and 3 will discuss relevant literature and describe the Norwegian Education reform. Sections 4 and 5 describe our empirical strategy and data. Section 6 discusses the effect of the Norwegian education reform on educational attainment and earnings, and Section 7 presents our results. Section 8 presents some specification checks and Section 9 then concludes.

\footnotetext{
${ }^{2}$ See Aakvik, Salavanes, and Vaage, 2003. Results on the impact of similar reforms on educational attainment also exist for Sweden, see Meghir and Palme (2003), and for England and Ireland, see Harmon
} 


\section{Background Information}

The recent literature has taken three broad approaches to identify the intergenerational transmission of human capital: identical twins, adoptees, and instrumental variables. ${ }^{3}$ Behrman and Rosenzweig (2002) use data on pairs of identical twin parents to "difference out" any correlation attributable to genetics. Despite observing a positive correlation between mother's education and child's education, the authors find a negative and almost significant relationship between mother's schooling and child's schooling once one looks within female monozygotic twin pairs, thereby differencing out any genetic factors that influence children's schooling. The analogous fixed effects exercise using male monozygotic twin pairs gives coefficients for father's education that are about the same size as the OLS estimates. Recent work by Antonovics and Goldberger (2003), however, calls into question these results and suggests that the findings are quite sensitive to the coding of the data. Also, it may be unrealistic to assume that twins differ in terms of education but not in terms of any other characteristic or experience that may influence the education of their offspring. ${ }^{4}$

Plug (2004) uses data on adopted children to investigate the causal relationship between parental education and child education. If children are randomly placed with adoptive parents, the relationship between parental education and child education cannot simply reflect genetic factors. Plug finds a positive effect of father's education on child education but no significant effect for mothers. Unfortunately, there are a number of limitations of this approach: sample sizes are tiny, children are not randomly placed with

and Walker (1995) and Oreopoulos (2003).

${ }^{3}$ More generally, there is a huge literature in both economics and sociology that studies intergenerational persistence of socio-economic status. See, for example, Solon (1999), and Hauser and Logan (1992).

${ }^{4}$ See Griliches (1979) and Bound and Solon (1999) for demonstrations that biases using sibling and twin 
adoptive parents, and the correlation between parents' education and child education could be picking up the effects of any unobserved parental characteristic (patience, ability) that may influence child outcomes. ${ }^{5}$

Closest to our paper is work by Chevalier (2003) and Oreopoulos, Page, and Stevens (2003) who use changes in compulsory schooling laws to identify the effect of parental education on their children's educational outcomes. ${ }^{6}$ Chevalier uses a change in the compulsory schooling laws in Britain in 1957 and finds a large positive effect of mother's education on her child's education but no significant effect of paternal education. However, this paper suffers from the fact that the legislation was implemented nationwide; as a result, the identifying variation in parental education arises both from secular trends in education and the once-off change in the law. ${ }^{7}$ Second, the sample only includes children who are still living at home with their parents and hence loses observations in a non-random fashion. Oreopoulos, Page and Stevens use compulsory schooling legislation in the U.S. (which occurred in different states at different times) to identify the effect of parents' educational attainment on children's; as a result, they are able to circumvent the problem encountered by Chevalier of coincident time effects. However, because of limitations of the U.S. census data, they are only able to look at children's grade retention as their outcome measure; a unique aspect of our work is that

fixed effects may be as big or bigger than OLS biases.

${ }^{5}$ Sacerdote (2002) also uses adoptees to distinguish the effect of family background on children's outcomes from genetic factors; however, the focus of his paper is the general impact of family socio-economic status as opposed to the causal impact of parent's education.

${ }^{6}$ Magnuson (2003) uses random assignment into a "human capital development" program for welfare mothers as an instrument for mother's educational attainment and finds evidence of an effect of mother's education on children's academic school readiness. Her work, however, examines the impact on young children and does not address the question of how it affects children's ultimate education decisions. ${ }^{7}$ Ignoring the existence of cohort effects may be a particular problem in this context as less-educated individuals are more likely to have children while young and so in a sample of individuals with children of a certain age, older individuals are likely to have more education. Thus, one would like to control for 
we are able to follow children even after they have moved out of their parents' home and observe final educational attainment.

\section{The Norwegian Primary School Reform}

In 1959, the Norwegian Parliament legislated a mandatory school reform. Prior to the reform, children started school at the age of seven and finished compulsory education after seven years, i.e. at the age of fourteen. In the new system, the starting age was still seven years old, but the time spent in compulsory education was now nine years.

In addition, the reform standardized the curriculum and increased access to schools, since the 9 years of mandatory school was eventually made available in all municipalities. The goal of standardizing the curriculum was to improve the average level of quality of the schools; the increase in mandatory education was therefore likely accompanied by an improvement in school quality. As a result, our estimates will incorporate both the increase in years of education along with an improvement in the quality. Given the positive correlation between the two, we will likely overestimate the effect of extra years of education on children's educational attainment.

The parliament mandated that all municipalities (the lowest level of local administration) must have implemented the reform by 1973; as a result, although it was started in 1960, implementation was not completed until 1972. ${ }^{8}$ Thus, for more than a decade, Norwegian schools were divided into two separate systems; which system you were in depended on the year you were born and the municipality in which you lived.

\footnotetext{
unrestricted age effects for parents.

${ }^{8}$ The reform had already started on a small and explorative basis in the late 1950s, but applied to a negligible number of students because only a few small municipalities, each with a small number of schools, were involved. See Lie (1974), Telhaug (1969), and Lindbekk (1992), for descriptions of the
} 
The first cohort that could have been involved in the reform was the one born in 1947. They started school in 1954, and (i) either finished the pre-reform compulsory school in 1961, or (ii) went to primary school from 1954 to 1960 , followed by the post-reform middle school from 1960 to 1963 . The last cohort who could have gone through the old system was born in $1958 .{ }^{9}$

To receive funds from the government to implement the reform, municipalities had to present a plan to a committee under the Ministry of Education. Once approved, the costs of teachers and buildings were provided by the national government. While the criteria determining selection are somewhat unclear, the committee did want to ensure that implementation was representative of the country, conditional on having an acceptable plan. (Telhaug, 1969, Mediås, 2000).

Because we control for municipality fixed effects, it is not necessary that the timing of the reform be unrelated to municipality characteristics. However, it is useful to understand the determinants of the timing of the reform across municipalities. Previous research has found no relationship between municipality characteristics such as average earnings, taxable income, and educational levels, and the timing of implementation (see Lie 1973, 1974). To examine this issue further, in Appendix Table 1 we regress the year of implementation on different background variables based on municipality averages, including parental income, the level of education, average age, the size of the municipality, and county dummies (there are 20 counties in Norway). Consistent with the existing literature, there appears to be no systematic relationship between the timing of implementation and average earnings, education levels, average age, the fraction of

${ }^{9}$ Similar school reforms were undertaken in many other European countries in the same period, notably 
individuals with fewer than 9 years of schooling, urban/rural status, industry or labor force composition, municipality unemployment rates in 1960, or the share of individuals who were members of the Labor party (the most pro-reform dominant political party).

\section{Identification Strategy}

Our source of exogenous variation in parental education is the education reform in Norway that increased the number of years of compulsory schooling from 7 to 9 years and was implemented over a 12 year period from 1960 to 1971 in different municipalities at different times. We then observe the children of this generation in 2000 .

Our empirical model is summarized by the following two equations:

$$
\begin{aligned}
& E D=\beta_{0}+\beta_{1} E D^{p}+\beta_{2} A G E+\beta_{3} F E M A L E+\beta_{4} A G E^{p}+\beta_{5} M U N I C I P A L I T Y^{P}+\varepsilon \\
& E D^{P}=\alpha_{0}+\alpha_{1} R E F O R M^{p}+\alpha_{2} A G E+\alpha_{3} F E M A L E+\alpha_{4} A G E^{p}+\alpha_{5} M U N I C I P A L I T Y^{P}+v
\end{aligned}
$$

In equations (1) and (2), ED is the number of years of education obtained by the child, AGE refers to a full set of years of age indicators, MUNICIPALITY refers to a full set of municipality indicators, and REFORM equals 1 if the individual was affected by the education reform and 0 otherwise. In all cases, the superscript $p$ denotes parent, so that, for example, $\mathrm{AGE}^{\mathrm{p}}$ refers to a full set of indicator variables for the age of the parent. We estimate the model using Two Stage Least Squares (2SLS) so that equation (2) is the first stage and $R E F O R M^{p}$ serves as an instrumental variable for $E D^{P}$.

There are two points to note about equations (1) and (2): First, both equations contain fixed cohort effects (to allow for secular changes in educational attainment over time) and municipality effects for parents. Even if the reform was implemented first in 
areas with certain unobserved characteristics, consistent estimation is still achieved so long as (a) these characteristics are fixed over time during the 12-year period or (b) implementation of the reform is not correlated with changes in these characteristics or (c) these characteristics are not related to the schooling of the children of this generation. ${ }^{10}$

Second, we have included age indicators for the children to allow for the fact that not all children in our sample have finished schooling by 2000. Child's age may be endogenous because parents choose the timing of births; therefore, in Section 8, we report estimates for specifications that exclude child age controls.

\section{Restricting the Sample}

Because the primary effect of the reform is at the bottom of the educational distribution, we conduct much of our analysis on the sample of mothers/fathers who have 9 or fewer years of education. The additional assumptions we make in doing this are 1) that individuals who get 9 years of education after the reform would have received 9 years or less of education if the reform had not been in effect, and 2) that individuals who got 9 years or less of education before the reform would have received 9 years of education if the reform had been in effect. ${ }^{11}$

In return for making these additional assumptions and restricting the sample we are able to estimate a much stronger first stage and obtain more precisely estimated second stage coefficients. ${ }^{12}$ In Section 8 , we describe features of the data that suggest that our assumptions are not unreasonable.

\footnotetext{
${ }^{10}$ We have also tried allowing for municipality-specific time trends as well as county by year fixed effects. Our results were insensitive to the inclusion of these extra variables.

${ }^{11}$ This second assumption rules out spillover effects of the reform of the sort that some signaling models imply.

${ }^{12}$ We have also tried using characteristics of the parents of our parents to split the sample based on predicted parental education rather than actual parental education. This approach gave us estimates that are consistent with the ones we report but were very imprecisely estimated.
} 


\section{Data}

Our data come from linked administrative data that cover the entire population of Norwegians aged 16-74. ${ }^{13}$ We include cohorts of parents born between 1947 and 1958 in our sample. The sample of children includes the children of these parents who are aged 25 - 35 in 2000 . Note that a great advantage of our data set over others in the literature is that we can link adult children in 2000 to characteristics of their parents, even in cases where the children do not live with their parents. Table 1 provides summary statistics for the individuals in our sample. ${ }^{14}$

To determine whether parents were affected by the reform, we need to link each parent to the municipality in which they grew up. We do this by matching the administrative data to the 1960 census. From the 1960 census, we know the municipality in which the parent's mother lived in $1960 .{ }^{15}$ At that time, the parents we are using in the estimation are aged between 2 and $13 .^{16}$

Educational attainment is reported by the educational establishment directly to Statistics Norway, thereby minimizing any measurement error due to misreporting. The education register started in 1970; we use information from the 1970 Census for parents who completed their education before then. Thus, the register data are used for children

\footnotetext{
${ }^{13}$ See Møen, Salvanes and Sørensen (2003) for a description of the data set.

${ }^{14}$ Note that it sometimes occurs that one parent is in our sample while the other is not because only one of them is born during the 1947-1958 period.

${ }^{15}$ Since very few children live with their father in the cases where parents are not living together, we should only have minimal misclassification by applying this rule.

${ }^{16}$ One concern is that there may be selective migration into or out of municipalities that implement the reform early. However, since the reform implementation did not occur before 1960, this could only be a problem for us to the extent that families anticipated where the reform would be implemented first and made mobility decisions prior to the 1960 census. Any reform-induced mobility subsequent to 1960 may affect the precision of our 2SLS estimates but not their consistency. Evidence from Meghir and Palme (2003) for Sweden and Telhaug (1969) for Norway suggest that reform-induced migration was not a
} 
and all but the earliest cohorts of parents who did not get any additional education after 1970. Census data are self reported but the information is considered to be very accurate; there are no spikes or changes in the education data from the early to the later cohorts.

Our primary data source on the timing of the reform in individual municipalities is the volume by Ness (1971). To verify the dates provided by Ness, we examined the data to determine whether or not there appears to be a clear break in the fraction of students with less than 9 years of education. In the rare instance when the data did not seem consistent with the timing stated in Ness, we checked these individual municipalities by contacting local sources. If the reform took more than one year to implement in a particular municipality or we were not able to verify the information given in Ness (1971), we could not assign a reform indicator to that municipality. We are able to successfully calculate reform indicators for 545 out of the 728 municipalities in existence in 1960 (which constitutes $74 \%$ of the individuals in our sample).

\section{The Effects of the Reform on Educational Attainment and Earnings}

There is a significant literature demonstrating the effect of compulsory schooling laws on educational attainment. ${ }^{17}$ In the case of the Norwegian reform, the increase in compulsory schooling had a large effect on educational attainment at the bottom of the distribution. Table 2 shows the distribution of education averaged over the 2 years prior to the reform and the two years immediately after the reform including the year the reform was implemented. It is clear from this table that the primary effect of the reform was to reduce the proportion of people with fewer than 9 years of education from $12 \%$ to

\footnotetext{
significant consideration.

${ }^{17}$ See, for example, Acemoglu and Angrist (2001) for work on the U.S., and Oreopoulos (2003) for work
} 
$3 \%$, with a new spike at 9 years. ${ }^{18}$

There is also substantial evidence that the additional education induced by the reform has a positive and statistically significant effect on earnings. OLS results for the return to education in Norway are about .07; 2SLS estimates for our cohorts using the reform as an instrument give estimates of .040 (0.013) for men and $.050(0.016)$ for women. Thus, the return to reform-induced education is both positive and statistically significant. Aakvik, Salvanes, and Vaage (2003) examine this issue in more detail and find heterogeneity in the returns, with returns as high as .10 for some groups.

\section{Results}

\section{Results for the Full Sample}

The OLS results for equation (1) are presented in Table 3, Column 1. As

expected, we find a positive relationship between the years of education of the parents

and their child's education. ${ }^{19}$ This is true, regardless of whether we match mothers to sons, mothers to daughters, fathers to sons, or fathers to daughters. Our estimates suggest that increasing a parent's education by a year increases the child's education by about

on Europe.

${ }^{18}$ The presence of some individuals with fewer than 9 years of schooling when the reform is in place reflects the fact that compliance with the law was not $100 \%$ and some individuals dropped out before completing compulsory schooling. It may also reflect the fact that, in some municipalities, the reform was implemented over several years and also possibly some error in the dating of reform implementation. These factors will tend to reduce the precision of our estimates without affecting consistency. Pre-reform, students could choose between a 3 year or a 5 year high school track after completing the 7 years of compulsory schooling. After the reform, this choice no longer existed and the standard high school track involved 3 years after the compulsory 9 years of schooling. As a result, the educational distribution appears to have a "hole" at 10 years of education after the reform (See Table 2); individuals who would have done the 3 year high school track before the reform would now ultimately achieve 10,11 or 12 years of schooling. This is consistent with the fact that the proportion of individuals with 10-12 years of education is similar before and after the reform.

${ }^{19}$ In both the OLS and 2SLS analysis we report robust standard errors that allow for clustering at the parent's municipality-parent's cohort level. To deal with possible concerns about the effects of serial correlation on the standard errors, we have also experimented with clustering by parent's municipality and 
$0.20-0.25$ of a year. ${ }^{20}$ While the sample size varies, particularly between the father and mother regressions (due to our inability to match fathers who were not living with the family at the time of the 1960 census), our estimates are quite similar across samples.

Column 2 then presents 2SLS results, where the instrument is the indicator for whether or not the father/mother was affected by the school reform in Norway. The 2SLS results are imprecisely estimated and are all statistically insignificant. The main reason for the lack of precision is the relatively weak first stage relationship between the reform and years of education of the father/mother: the t-statistics for the reform indicator in the first stage are about 5. (See Table 3a for the first stage estimates.) These relatively small t-statistics result from the fact that the reform is affecting only the relatively small fraction of the population with 9 or fewer years of education. It is clear that to effectively use the reform as a source of exogenous variation, one needs to focus on the very bottom tail of the education distribution, where the reform has bite.

Results for the Restricted Sample

The results for the sample of parents with 9 or fewer years of education are in Columns 3 and 4 of Table 3, and the first stage estimates are in Table 3a. The OLS estimates are quite similar to those obtained from the full sample. However, consistent with the evidence presented earlier, the first stage for the low education sample is much stronger than that for the full sample.

As expected, the 2SLS estimates (Column 4) are quite similar to the results for the full sample but much more precisely estimated. For fathers, the estimates are all close to zero, statistically insignificant, and the father-all and father-son estimates are statistically

found the 2SLS standard errors to be almost identical.

${ }^{20}$ This is consistent with the general findings in this literature; results from the U.S. and U.K. suggest 
different from the OLS estimates. For mothers, there is a positive effect of maternal education on the education of sons but no such relationship for daughters (the motherdaughter coefficient is also statistically different from the OLS coefficient). Taken as a whole, the results indicate that the positive correlation between parent's and children's education largely represents positive relationships between other factors that are correlated with education. These could be ability, family background, income or other factors. The true causal effect of parental education on child education appears to be weak. $^{21}$

Figure 1 provides a visual representation of our results for the restricted sample, presenting the effects of the reform on parents' education (the first stage) as well as the effects of the reform on the children (the reduced form) after taking out municipality and cohort effects. ${ }^{22}$ Time zero represents the year of implementation of the reform. We see that the reform did have a large impact on parents' educational attainment. It is also clear, however, that the effect of the reform on children's educational attainment is small, with only the mother/son pair demonstrating any real relationship.

Our finding that the IV estimates are smaller than the OLS estimates is intuitive in that we expect education choice to be positively correlated with unobserved ability. However, this finding is not in keeping with much of the returns to education literature. Typically, IV estimates are found to be larger than OLS estimates. We suspect a few reasons for this divergence. First, our education data are of very high quality and

intergenerational education elasticities between 0.20 and 0.45 (Dearden et al., 1997; Mulligan, 1999).

${ }^{21}$ We also estimated equations with the education of both parents included; in this case, IV estimates are identified off of the fact that many individuals are of a different age or grew up in a different municipality than their spouse. Results are similar in that we find a positive effect of maternal education but no effect of father's education.

${ }^{22}$ Note that individual points should be interpreted with caution, as there is substantial sampling error. 
probably have little or no measurement error. Thus, unlike in other studies, our OLS estimates may not be subject to downward biases due to measurement error. Second, our use of an education reform and our ability to control for both cohort and municipality effects leads to greater confidence that the instrument is not correlated with unobserved ability and therefore our IV estimates are not upward biased. Finally, high IV estimates in the endogenous education literature are often rationalized by heterogeneous returns to education with particularly high returns for the group of people whose behavior is impacted by the instrument being used. Because credit constraints are unlikely to have been a major determinant of educational choice in the lower tail of the Norwegian distribution at this time, it is plausible that the returns to education for individuals impacted by the reform are no higher than average.

\section{Robustness/Specification Checks}

Having found little causal effect of parents' education on children's educational attainment, we next conduct a number of robustness checks to verify our findings (see Table 4). ${ }^{23}$ First, because education may impact the timing of childbearing, children's age may be endogenous. In Columns 1 and 2, we re-estimated the specifications excluding child's age from the regression. As one can see from the results, this does not affect our conclusions. A related issue is whether the reform affects the decision to have children; in this case, the parents who have children in our sample are a selected group and our 2SLS estimates may be biased. We checked this possibility by examining whether the reform affects the probability that a potential parent ends up in our sample (by having at least one child aged 25 or more in 2000) and found no evidence of this. 
A second concern is that mismeasurement of the exact timing of the reform, or lags in implementation (given the necessity to build new infrastructure), could bias the 2SLS estimates. To check this, we have tried dropping all observations from the reform year and the years immediately preceding and following it. As can be seen from Table 4, Columns 3 and 4, however, this change in sample had little effect on the results.

A third potential concern is that, because of the timing of the reform, we only observe children of parents who had children relatively young. While there is little that we can do to remedy this, we can test the sensitivity of our results to using only the early cohorts of parents. If the results are similar to those from the full sample, it suggests they are unlikely to be biased by this constraint. Table 4 , Columns 5 and 6 present the results using only the first 6 of our 12 cohorts (parents born before 1953). While the mother-son estimate is slightly larger than before, the overall conclusions are the same.

Next, we address two potential censoring concerns. First, children of loweducation parents may always get the minimum education mandated by law and, as a result, we would see all these children clustered at 9 years of education. This would cause our estimates for this group to be close to zero even when the "true" effect of parental education on desired education is larger. However, there is only a small density at 9 years of education (around 9\%), so this is unlikely to be a problem. ${ }^{24}$

The second concern is that some individuals have not completed schooling by age 25 (approximately $7 \%$ in our restricted sample). We have tested the sensitivity of our results to estimating the relationship between parents' education and children's education using instrumental variables in a tobit framework; the results are very similar to those

\footnotetext{
${ }^{23}$ Unless otherwise specified, we are focusing on the restricted sample in this section.

${ }^{24}$ Estimates were also unaffected when we treated these observations as left censored and applied a tobit IV
} 
presented here, so censoring bias does not seem important.

The Validity of Restricting the Sample to Parents with Less Than 10 Years of Education

Finally, as discussed earlier, the estimates from the restricted sample may be biased if there are systematic changes in the composition of the group of parents with less than 10 years of education. These could arise if the proportion of individuals with less than 10 years changes after reform implementation. However, in Table 2, we see that the proportion of individuals with 9 years or less of education stays constant when we compare two years before to two years after the reform.

To further investigate this issue, we test whether, conditional on cohort and municipality effects, the proportion of individuals with less than 10 years of education in municipality-year cells is related to the reform. We find no statistically significant effect of the reform once we exclude observations from the reform year and the year immediately preceding and following reform implementation. This suggests that there may be no significant spillover effects of the reform; those who obtained 9 or fewer years of education before the reform would have continued to do so after the reform.

Additionally, we have examined the family background characteristics of the individuals (parents) with 9 or fewer years of education in the years before and after the reform to check and see if the composition of our sample appears to have changed. If, for example, there were positive spillover effects of the reform, we might expect to see the post-reform individuals with 9 or fewer years of education looking observably "worse" than those prior to the reform. The variables we can look at include the log of family income (from the 1970 census) and the educational attainment of the mothers and fathers (of our parents). When we regress each of these variables on the reform indicator along approach. 
with cohort and municipality effects for the sample of individuals with 9 or fewer years of education, we find no evidence of any compositional change after the reform.

As a more rigorous test for composition bias, we have re-estimated the specifications using a sample of the lowest $20 \%$ of the education distribution in each municipality in each year (breaking ties randomly so that we have exactly $20 \%$ of observations per municipality). This approach involves weaker assumptions than the less than 10 years of education sample split in that it does not require the proportion less than 10 to remain constant. What is required is that the implementation of the reform in a municipality had no systematic effect on the relative position in the educational distribution of individuals in that cohort in that municipality. The results, reported in Columns 7 and 8 of Table 4 , indicate that using the bottom $20 \%$ of the distribution gives quite similar results to using the less than 10 sample split.

As a final check, we have also conducted our estimation on samples with higher educational cutoff points. When we look at the results obtained for the sample of parents with fewer than 12 years of education (or fewer than 13 years of education), they are as we would expect; the coefficient estimates are very similar to those from the sample of parents with fewer than 10 years of education but the standard errors are larger.

These numerous checks suggest that our results are not being driven by the use of our restricted sample.

\section{Conclusions}

By using the increased educational attainment induced by the change in the compulsory schooling legislation in Norway in combination with a unique dataset 
containing the entire population of the country, we are able to estimate the causal relationship between parents' education and that of their children. Despite strong OLS relationships, we find little causal relationship between parent education and child education. The one exception is among mothers and sons; when mothers increase their educational attainment, their sons get more education as well. These results are robust to a number of specification checks.

What explains these findings? In the working paper version of this paper (Black et al., 2003), we examined some of the possible mechanisms through which this relationship may be working, including whether the women who received more education due to the reform married better educated or wealthier men (they don't) and whether these more highly educated women are making a quantity/quality tradeoff by having fewer children (they aren't). While we are able to rule out a few mechanisms, a number remain, including the most direct, which suggests that higher maternal education may reduce the cost (in terms of effort) of education for the child. ${ }^{25}$

Our results provide limited support for intergenerational spillovers as a compelling argument for compulsory schooling laws. However, it is important to remember that we are studying an education reform that increased education at the bottom tail of the distribution. It is plausible that a policy change that increased enrollment in higher education would have been transmitted more successfully across generations. Also, our results from Norway may not generalize to countries that have more costly education and higher returns to skills. While these results are compelling, much more work needs to be done on this important topic.

\footnotetext{
${ }^{25}$ See Black, Devereux, and Salvanes (2003) for a more complete discussion of the findings.
} 


\section{References}

Aakvik, Arild, Kjell G. Salvanes, and Kjell Vaage. 2003. "Measuring the Heterogeneity in the Returns to Education in Norway Using Educational Reforms." CEPR DP 4088 .

Acemoglu, Daron and Joshua Angrist. 2001. "How Large Are Human Capital Externalities? Evidence from Compulsory Schooling Laws." In NBER Macroeconomics Annual 2000, B. S. Bernanke and K. Rogoff, eds. MIT Press: Cambridge, MA.

Antonovics, Kate L. and Arthur S. Goldberger. 2003. "Do Educated Women Make Bad Mothers? Twin Studies and the Intergenerational Transmission of Human Capital." Mimeo.

Behrman, Jere R. and Mark R. Rosenzweig. 2002. "Does Increasing Women's Schooling Raise the Schooling of the Next Generation?" American Economic Review, 91(1), pp 323-334.

Black, Sandra E., Paul J. Devereux and Kjell G. Salvanes. 2003. "Why the Apple Doesn't Fall Far: Understanding Intergenerational Transmission of Human Capital.” NBER Working Paper 10,066, November 2003.

Bound, John and Gary Solon. 1999. "Double Trouble: On the Value of Twins-Based Estimation of the Returns to Schooling." Economics of Education Review, 18, $169-182$.

Chevalier, Arnaud. 2003. "Parental Education and Child's Education: A Natural Experiment." Mimeo, University College Dublin.

Dearden, L, S. Machin and H. Reed. 1997. "Intergenerational Mobility in Britain." Economic Journal, 107, 47-66.

Griliches, Zvi. 1979. "Sibling Models and Data in Economics: Beginnings of a Survey." Journal of Political Economy, 87, 37-64.

Harmon, C. and Ian Walker. 1995. "Estimates of the Economic Return to Schooling for the United Kingdom." American Economic Review, 85, 1278-86.

Hauser, Robert, and John Allen Logan. 1992. "How not to Measure Intergenerational Occupational Persistence." American Journal of Sociology, 97(6), 1689-1711.

Leschinsky, A. and Mayer, K. A. (eds.) (1990). The Comprehensive School Experiment Revisited: Evidence from Western Europe. Frankfurt am Main.

Lie, Suzanne S. (1973) The Norwegian Comprehensive School Reform. Strategies for 
Implementation and Complying with Regulated Social Change. A Diffusion Study. Part 1 and II. Washington, D.C., The American University.

Lie, Suzanne S. (1974) "Regulated Social Change: a Diffusion Study of the Norwegian Comprehensive School Reform”, Acta Sociologica, 16(4), 332-350.

Lindbekk, Tore (1992) "School Reforms in Norway and Sweden and the Redistribution of Educational Attainment." Journal of Educational Research, 37(2), 129-49.

Magnuson, Katherine. (2003). "The Effect of Increases in Welfare Mothers' Education on Their Young Children's Academic and Behavioral Outcomes: Evidence from the National Evaluation of Welfare-to-Work Strategies Child Outcomes Study." Mimeo, September.

Mediås, Olav A. (2000). Fra griffel til PC. In Norwegian. (From pencil to PC). Steinkjer: Steinkjer kommune.

Meghir, Costas and Marten Palme. 2003. "Ability, parenthal background and education policy: empirical evidence from a social experiment", mimeo, Stockholm School of Economics.

Mulligan, C. 1999. "Galton versus the human capital approach to inheritance." Journal of Political Economy, 107, 184-224.

Ness, Erik (ed.). (1971). Skolens Årbok 1971. In Norwegian. (The primary school yearbook 1971.) Oslo: Johan Grundt Tanum Forlag.

Oreopoulos, P. (2003). “Do dropouts drop out too soon?” Mimeo, University of Toronto.

Oreopoulos, Philip, Marianne E. Page and Ann Huff Stevens. (2003). "Does Human Capital Transfer from Parent to Child? The Intergenerational Effects of Compulsory Schooling." Mimeo, November.

Plug, Erik. 2004. "Estimating the Effect of Mother's Schooling on Children's Schooling Using a Sample of Adoptees", American Economic Review, 94(1), 358-368.

Sacerdote, Bruce (2002). "The Nature and Nurture of Economic Outcomes." American Economic Review, 92(2), 344-348.

Solon, Gary (1999). "Intergenerational Mobility in the Labor Market." In Handbook of Labor Economics, Volume 3. O. Ashenfelter and D. Card, editors. pp 1761-1800.

Telhaug, Arne O. (1969). Den 9-årige skolen og differensieringsproblemet. En oversikt over den historiske utvikling og den aktuelle debatt. In Norwegian. (The 9-years compulsory school and the tracking problem. An overview of the historical development and the current debate). Oslo: Lærerstudentenes Forlag. 


\section{Table 1: Summary Statistics}

\begin{tabular}{lrrr}
\hline & Observations & \multicolumn{1}{c}{ Mean } & Std. Dev. \\
\hline Children & & & \\
Age & 173,630 & 27.79 & 2.34 \\
Education & 173,630 & 12.20 & 1.97 \\
Earnings & 173,630 & 202,296 & 138,859 \\
Sex (Female / Male) & 173,630 & 0.49 & 0.50 \\
Mothers & & & \\
Age & 145,385 & 49.55 & 2.64 \\
Education & 144,770 & 10.46 & 2.23 \\
Earnings & 142,374 & 171,246 & 119,324 \\
Fathers & & & \\
Age & 97,474 & 50.51 & 2.18 \\
Education & 97,117 & 11.01 & 2.54 \\
Earnings & 93,670 & 309,711 & 227,710 \\
\hline
\end{tabular}

Sample includes children who were between the ages of 25 and 35 in 2000 who had at least one parent born during the reform period. Parental age and education are reported only for parents who are members of the reform cohorts. 


\section{Table 2: Distribution of Education Two Years Before and After the Reform}

\begin{tabular}{lrr}
\hline $\begin{array}{l}\text { Years of } \\
\text { Education }\end{array}$ & \multicolumn{1}{l}{ Before } & \multicolumn{1}{l}{ After } \\
\hline 7 & $3.5 \%$ & $1.2 \%$ \\
8 & $8.9 \%$ & $1.6 \%$ \\
9 & $3.4 \%$ & $12.9 \%$ \\
10 & $29.5 \%$ & $26.6 \%$ \\
11 & $8.5 \%$ & $8.9 \%$ \\
12 & $17.2 \%$ & $19.1 \%$ \\
13 & $6.7 \%$ & $6.6 \%$ \\
14 & $5.4 \%$ & $5.8 \%$ \\
15 & $2.7 \%$ & $3.4 \%$ \\
$16+$ & $14.2 \%$ & $14.1 \%$ \\
$\mathrm{~N}$ & 89,320 & 92,227 \\
\hline
\end{tabular}

Before indicates education distribution of cohorts in the two years prior to the reform, while After indicates the distribution of those two years post reform. Note that, because the reform occurred in different municipalities at different times, the actual year of the reform varies by municipality. 
Table 3

Relationship between Parents' and Children's Education

\begin{tabular}{|c|c|c|c|c|}
\hline & \multicolumn{4}{|c|}{ Dependent Variable: Children's Education } \\
\hline & \multicolumn{2}{|c|}{ Full Sample } & \multicolumn{2}{|c|}{ Parent's Education $<10$} \\
\hline & OLS & IV & OLS & IV \\
\hline \multirow[t]{3}{*}{ Mother - All } & $0.237 *$ & 0.076 & $0.211 *$ & $0.122 *$ \\
\hline & $(0.003)$ & $(0.139)$ & $(0.017)$ & $(0.043)$ \\
\hline & \multicolumn{2}{|c|}{$\mathrm{N}=143,579$} & \multicolumn{2}{|c|}{$\mathrm{N}=39,605$} \\
\hline \multirow[t]{3}{*}{ Mother - Son } & $0.212 *$ & 0.199 & $0.197^{*}$ & $0.176^{*}$ \\
\hline & $(0.004)$ & $(0.185)$ & $(0.021)$ & $(0.054)$ \\
\hline & \multicolumn{2}{|c|}{$\mathrm{N}=73,663$} & \multicolumn{2}{|c|}{$\mathrm{N}=20,135$} \\
\hline \multirow[t]{3}{*}{ Mother - Daughter } & $0.264 *$ & -0.029 & $0.225^{*}$ & 0.066 \\
\hline & $(0.004)$ & $(0.187)$ & $(0.024)$ & $(0.063)$ \\
\hline & \multicolumn{2}{|c|}{$\mathrm{N}=69,916$} & \multicolumn{2}{|c|}{$\mathrm{N}=19,470$} \\
\hline \multirow[t]{3}{*}{ Father - All } & $0.217 *$ & 0.030 & $0.200 *$ & 0.041 \\
\hline & $(0.003)$ & $(0.132)$ & $(0.022)$ & $(0.062)$ \\
\hline & \multicolumn{2}{|c|}{$\mathrm{N}=96,275$} & \multicolumn{2}{|c|}{$\mathrm{N}=22,148$} \\
\hline \multirow[t]{3}{*}{ Father - Son } & $0.209 *$ & 0.029 & $0.151^{*}$ & 0.008 \\
\hline & $(0.004)$ & $(0.171)$ & $(0.027)$ & $(0.071)$ \\
\hline & \multicolumn{2}{|c|}{$\mathrm{N}=49,492$} & \multicolumn{2}{|c|}{$\mathrm{N}=11,235$} \\
\hline \multirow[t]{3}{*}{ Father - Daughter } & $0.226^{*}$ & 0.023 & $0.244^{*}$ & 0.081 \\
\hline & $(0.004)$ & $(0.186)$ & $(0.033)$ & $(0.094)$ \\
\hline & \multicolumn{2}{|c|}{$\mathrm{N}=46,783$} & \multicolumn{2}{|c|}{$\mathrm{N}=10,913$} \\
\hline
\end{tabular}

Sample includes children aged 25-35. Robust standard errors in parentheses. Each estimate represents the coefficient from a different regression. All specifications include dummies for parent's age, parent's municipality and child's age. *significant at 5\% level 
Table 3a

First Stage Results

\begin{tabular}{ccccc}
\hline & \multicolumn{2}{c}{ Full Sample of Parents } & \multicolumn{2}{c}{ Parents' Education $<10$ Years } \\
& $\begin{array}{c}\text { Mother's } \\
\text { Education }\end{array}$ & $\begin{array}{c}\text { Father's } \\
\text { Education }\end{array}$ & $\begin{array}{c}\text { Mother's } \\
\text { Education }\end{array}$ & $\begin{array}{c}\text { Father's } \\
\text { Education }\end{array}$ \\
\hline All & $\begin{array}{c}.142^{*} \\
(.029)\end{array}$ & $\begin{array}{c}.192^{*} \\
(.042)\end{array}$ & $\begin{array}{c}.749^{*} \\
(.017)\end{array}$ & $.795^{*}$ \\
& & $.024)$ & $.814^{*}$ \\
Sons & $.127^{*}$ & $(.051)$ & $.742^{*}$ & $(.029)$ \\
& $(.035)$ & $.197^{*}$ & $.755^{*}$ & $.779^{*}$ \\
Daughters & $.161^{*}$ & $(.050)$ & $(.019)$ & $(.027)$ \\
\hline
\end{tabular}

Each estimate represents the coefficient from a different regression. Robust standard errors in parentheses. First stage also includes dummies for parent's age, parent's municipality, and child's age. *significant at $5 \%$ level. 
Table 4

\section{Robustness Checks}

\begin{tabular}{|c|c|c|c|c|c|c|c|c|}
\hline & \multicolumn{2}{|c|}{ Dropping Child's Age } & \multicolumn{2}{|c|}{$\begin{array}{l}\text { Dropping reform year along with } \\
\text { years before and after reform }\end{array}$} & \multicolumn{2}{|c|}{ Early Cohorts $(<1953)$} & \multicolumn{2}{|c|}{$\begin{array}{c}\text { Bottom } 20 \% \text { of Parents' } \\
\text { Distribution }\end{array}$} \\
\hline & (1) & (2) & (3) & (4) & (5) & (6) & (7) & (8) \\
\hline & OLS & IV & OLS & IV & OLS & IV & OLS & IV \\
\hline Mother-All & $\begin{array}{c}.217 * \\
(.017) \\
\mathrm{N}=39,605\end{array}$ & $\begin{array}{l}.127 * \\
(.043)\end{array}$ & $\begin{array}{c}.237^{*} \\
(.021) \\
\mathrm{N}=31,341\end{array}$ & $\begin{array}{l}.135^{*} \\
(.056)\end{array}$ & $\begin{array}{c}.245^{*} \\
(.021) \\
\mathrm{N}=29,374\end{array}$ & $\begin{array}{c}.128 \\
(.063)\end{array}$ & $\begin{array}{c}.301 * \\
(.016) \\
\mathrm{N}=26,362\end{array}$ & $\begin{array}{c}.079 \\
(.059)\end{array}$ \\
\hline Mother-Son & $\begin{array}{c}.201 * \\
(.021) \\
\mathrm{N}=20,135\end{array}$ & $\begin{array}{l}.182 * \\
(.054)\end{array}$ & $\begin{array}{c}.206^{*} \\
(.027) \\
\mathrm{N}=15,861\end{array}$ & $\begin{array}{l}.185^{*} \\
(.071)\end{array}$ & $\begin{array}{c}.221^{*} \\
(.026) \\
\mathrm{N}=14,944\end{array}$ & $\begin{array}{l}.243 * \\
(.075)\end{array}$ & $\begin{array}{c}.274 * \\
(.020) \\
\mathrm{N}=13,466\end{array}$ & $\begin{array}{l}.141^{*} \\
(.070)\end{array}$ \\
\hline Mother-Daughter & $\begin{array}{c}.233 * \\
(.024) \\
\mathrm{N}=19,470\end{array}$ & $\begin{array}{c}.072 \\
(.063)\end{array}$ & $\begin{array}{c}.273^{*} \\
(.029) \\
\mathrm{N}=15,480\end{array}$ & $\begin{array}{c}.073 \\
(.083)\end{array}$ & $\begin{array}{c}.262 * \\
(.029) \\
\mathrm{N}=14,430\end{array}$ & $\begin{array}{c}.014 \\
(.088)\end{array}$ & $\begin{array}{c}.308 * \\
(.023) \\
\mathrm{N}=12,883\end{array}$ & $\begin{array}{c}-.003 \\
(.083)\end{array}$ \\
\hline Father-All & $\begin{array}{c}.202 * \\
(.022) \\
\mathrm{N}=22,148\end{array}$ & $\begin{array}{c}.041 \\
(.062)\end{array}$ & $\begin{array}{c}.214^{*} \\
(.026) \\
\mathrm{N}=18,570\end{array}$ & $\begin{array}{c}.012 \\
(.102)\end{array}$ & $\begin{array}{c}.213^{*} \\
(.024) \\
\mathrm{N}=19,622\end{array}$ & $\begin{array}{c}.093 \\
(.072)\end{array}$ & $\begin{array}{c}.208^{*} \\
(.015) \\
\mathrm{N}=17,317\end{array}$ & $\begin{array}{l}-.016 \\
(.079)\end{array}$ \\
\hline Father-Son & $\begin{array}{c}.153^{*} \\
(.028) \\
\mathrm{N}=11,235\end{array}$ & $\begin{array}{c}.009 \\
(.071)\end{array}$ & $\begin{array}{c}.173^{*} \\
(.033) \\
\mathrm{N}=9,447\end{array}$ & $\begin{array}{l}-.010 \\
(.131)\end{array}$ & $\begin{array}{c}.163^{*} \\
(.031) \\
\mathrm{N}=9,980\end{array}$ & $\begin{array}{l}-.004 \\
(.082)\end{array}$ & $\begin{array}{c}.190^{*} \\
(.020) \\
\mathrm{N}=8,752\end{array}$ & $\begin{array}{c}.011 \\
(.101)\end{array}$ \\
\hline Father-Daughter & $\begin{array}{c}.247 * \\
(.033) \\
\mathrm{N}=10,913\end{array}$ & $\begin{array}{c}.078 \\
(.094)\end{array}$ & $\begin{array}{c}.250^{*} \\
(.041) \\
\mathrm{N}=9,123\end{array}$ & $\begin{array}{c}.071 \\
(.137)\end{array}$ & $\begin{array}{c}.256^{*} \\
(.037) \\
\mathrm{N}=9,642\end{array}$ & $\begin{array}{c}.183 \\
(.111)\end{array}$ & $\begin{array}{c}.261 * \\
(.023) \\
\mathrm{N}=8,465\end{array}$ & $\begin{array}{l}-.084 \\
(.125)\end{array}$ \\
\hline
\end{tabular}

Sample includes children aged 25-35. Robust standard errors in parentheses. Each estimate represents the coefficient from a different regression. All specifications include dummies for parent's age, parent's municipality and child's age (unless otherwise specified). In columns (1) to (6), the sample used is the sample of parents with less than 10 years of education. *significant at $5 \%$ level. 


\section{Appendix Table 1: \\ Timing of the Implementation of the Reform \\ Dependent Variable: Year of Reform}

\begin{tabular}{|c|c|c|}
\hline & Coefficient & Standard error \\
\hline County2 & -1.84 & .66 \\
\hline County3 & -1.90 & 4.36 \\
\hline County4 & .16 & .70 \\
\hline County5 & .05 & .74 \\
\hline County6 & -.99 & .92 \\
\hline County7 & -1.65 & .74 \\
\hline County 8 & -2.31 & .68 \\
\hline County 9 & -.72 & .59 \\
\hline County 10 & -3.55 & .93 \\
\hline County 11 & -1.41 & .65 \\
\hline County 12 & -.21 & .64 \\
\hline County 13 & -6.12 & 1.26 \\
\hline County14 & -.18 & .79 \\
\hline County 15 & 1.90 & .53 \\
\hline County 16 & -1.94 & .62 \\
\hline County 17 & .76 & .57 \\
\hline County 18 & -.61 & .54 \\
\hline County 19 & .44 & .63 \\
\hline Share of Fathers with Some College & 5.05 & 5.59 \\
\hline Share of Mothers with Some College & 21.98 & 11.32 \\
\hline Father's Income (mean) & -.004 & .005 \\
\hline Mother's Income (mean) & -.037 & .014 \\
\hline Father's Age (mean) & -.06 & .20 \\
\hline Mother's Age (mean) & -.19 & .25 \\
\hline Share of Municipality with Fewer than 9 Years of Education & .18 & 1.23 \\
\hline Size of Municipality/100 & .19 & .30 \\
\hline Unemployment Rate 1960 & -16.30 & 15.48 \\
\hline Share Workers in Manufacturing 1960 & .98 & 4.47 \\
\hline Share Workers in Private Services 1960 & 5.74 & 8.18 \\
\hline Share Labour Vote 1961 & 1.57 & 2.80 \\
\hline Constant term & 1980.51 & 9.69 \\
\hline
\end{tabular}

Robust standard errors. All variables are municipality level variables. 
Figure 1

Effect of Norwegian Education Reform on Education

First Stage (Effect on Parents)

Reduced Form (Effect on Children)

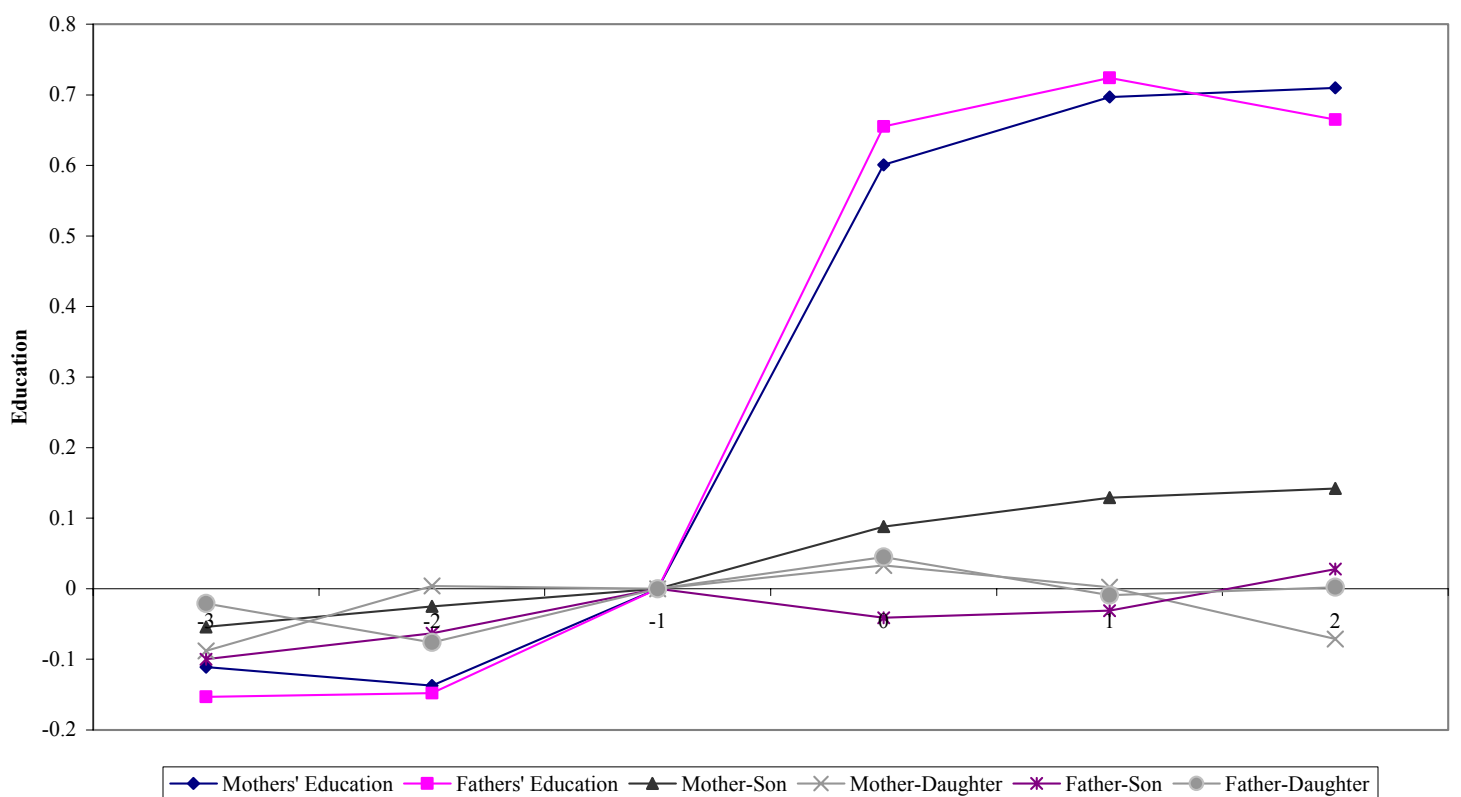

Note: Estimated on the restricted sample. Lines represent average education for each group with cohort and municipality effects taken out; time zero represents the year of the reform. 